\title{
HLA-B27 frequency in a group of patients with psoriatic arthritis
} Freqüência de HLA-B27 em uma amostra de pacientes com artrite psoriática

\author{
Danilo Garcia Ruiz ${ }^{1}$ \\ Omar Lupi ${ }^{3}$
}

\author{
Mário Newton Leitão de Azevedo²
}

\begin{abstract}
BACKGROUND: HLA-B27 is associated with spondyloarthritis, a group of diseases that includes psoriatic arthritis. OвJеCтіvEs: To describe the HLA-B27 frequency in a group of Brazilian patients with psoriatic arthritis and correlate its presence or absence with their clinical manifestations.

MEтHоDS: Cross-sectional study with 44 psoriatic arthritis patients of a Rheumatology clinic. Demographic and social data were recorded, as were skin and joints clinical examination. HLA-B27 was tested. All data were processed descriptively and comparatively by appropriate software. Parametric and non parametric tests were used with $5 \%$ statistical significance.

Results: HLA-B27 was negative in 32 of the 44 patients $(72,7 \%)$. Most of them were male, Caucasian, living in Rio de Janeiro, with plaque type psoriasis and average age of 52,9 years. There was statistical significant correlation between positive HLA-B27 and male gender $(p=0,004)$. Negative HLA-B27 had a tendency to correlate with hands and wrists arthritis $(p=0,07)$. There was an inverse significant correlation between HLA values and Schöber's test $(p=0,02)$.

ConCLUSION: Although HLA-B27 is negative in most of patients, it is significantly associated to male gender and inversely correlated with Schöber's test.

Keywords: Arthritis, psoriatic; HLA-B27 antigen; Spondylarthropathies

Resumo: Fundamentos: O HLA-B27 está associado às espondiloartrites, grupo de doenças que engloba, entre outras, a artrite psoriásica.

OBJETIVOS: Descrever a freqüência de HLA-B27 em uma amostra de pacientes brasileiros com artrite psoriásica e correlacionar sua presença ou ausência com as manifestações clínicas dos mesmos.

MÉTODOs: Estudo transversal avaliando 44 pacientes com artrite psoriásica de um ambulatório de Reumatologia. A avaliação consistia em registro de informações demográficas e sociais, exame clínico da pele e das articulações e pesquisa de HLA-B27. Os dados gerados foram tratados por meio de estatística descritiva e comparativa em Software apropriado. Foram utilizados testes paramétricos e não-paramétricos com significância estatística de 5\%.

Resultados: O HLA-B27 resultou negativo em 32 dos 44 pacientes estudados (72,7\%). A maioria dos pacientes era do sexo masculino, da raça branca, procedente do Rio de Janeiro, portador de psoríase em placas e com idade média de 52,9 anos. Houve associação estatisticamente significativa entre o HLA-B27 positivo e o sexo masculino $(p=0,004)$. O HLA-B27 negativo teve tendência à correlação com artrite de mãos e punhos $(p=0,07)$. Houve correlação inversa significativa entre os valores do HLA e do teste de Schöber $(\mathrm{p}=0,02)$.

CONCLUSÃO: Apesar do HLA-B27 ser negativo na maioria dos pacientes estudados, esteve significativamente associado ao sexo masculino e inversamente correlacionado ao teste de Schöber.

Palavras-chave: Antígeno HLA-B27; Artrite psoriásica; Espondiloartropatias
\end{abstract}

\footnotetext{
Received on 04.09.2011

Approved by the Advisory Board and accepted for publication on 03.03.2012.

* Work performed at the Rheumatology Service of the Hospital Universitário Clementino Fraga Filho - Universidade Federal do Rio de Janeiro - Rio de Janeiro (RJ), Brazil.

Financial Support: Danilo Garcia Ruiz is a post-graduate student at the Masters level and has a scholarship by Cnpq. The HLA-B27 research was financed with funds from the post-graduation in Internal Medicine of the Faculdade de Medicina da Universidade Federal do Estado do Rio de Janeiro (UFRJ) - Rio de Janeiro (RJ), Brazil.

Conflict of Interests: None.

Specialist in Rheumatology. M.Sc. in Internal Medicine, Federal University of Rio de Janeiro (UFRJ). Professor of Medicine, Faculdade Instituto Tocantinense Presidente Antônio Carlos (ITPAC) - Porto Nacional (TO), Brazil.

PhD - Deputy Chief of the Rheumatology Service of the Hospital Universitário Clementino Fraga Filho - Universidade Federal do Estado do Rio de Janeiro (HUCFF-UFRJ). Retired Associate Professor of the Faculdade de Medicina of the Universidade Federal do Estado do Rio de Janeiro (UFRJ) - Rio de Janeiro (RJ), Brazil.

PhD - Assistant Professor of the Universidade Federal do Estado do Rio de Janeiro (Uni-Rio), Permanent Professor of the Post-Graduation Course in Internal Medicine of the Universidade Federal do Rio de Janeiro (UFRJ) - Rio de Janeiro (RJ), Brazil. 


\section{INTRODUCTION}

Psoriatic arthritis is defined as a chronic inflammatory disease of synovial joints associated with psoriasis and usually rheumatoid factor negative. ${ }^{1}$

It is classified within the spondyloarthritis. This is a group of diseases characterized by arthritis of peripheral joints and axial skeleton and extra articular findings. Its true incidence is unknown but it is diagnosed in 7 to $40 \%$ of patients with psoriasis. Rheumatologic manifestations such as arthralgia may be present in $90 \%$ of them. ${ }^{2}$

Genetic factors implicated in pathogenesis of psoriatic arthritis refer to the presence of HLA haplotypes in affected individuals. In Caucasians, the presence of HLA-Cw6 alleles increases by 10 times the risk of developing psoriasis. ${ }^{3}$ The association between psoriasis, sacroiliitis and HLA-B27 is well known. ${ }^{4}$

HLA-B27 is present in $90-95 \%$ of patients with ankylosing spondylitis. ${ }^{5}$ This fact led the scientific community to believe that HLA-B27 was related only to spondylitis and axial diseases. However, in 1977 a group of psoriatic patients positive for HLA-B27 who were at increased risk of developing axial and peripheral arthritis including distal interphalangeal involvement was described. ${ }^{6}$ These were the first steps to better understand how HLA-B27 correlates with psoriasis and psoriatic arthritis.

This study aims to describe HLA-B27 frequency in a group of Brazilian patients with psoriatic arthritis and correlate its presence or absence with their clinical manifestations.

\section{PATIENTS AND METHODS}

This cross-sectional study was conducted from April 2010 to July 2011. From the data of the Rheumatology clinic 64 eligible patients diagnosed with psoriatic arthritis were identified. Were excluded 20 due to: two deaths, four which refused to participate, five with impossibility of locomotion to the hospital and nine without any current personal contact (phone number or address). The final convenience sample was composed of 44 patients with psoriatic arthritis under treatment at a Rheumatology clinic (HUCFF-UFRJ). Patients' individual evaluation was performed by recording demographic and social data, skin and joints clinical examination and research for HLA-B27. The study was approved by the hospital's ethics committee.

Data recorded were gender, psoriasis physical symptoms (scaling, itching, dry skin, erythema, bleeding) skin and joint involvement, extra articular manifestations (enthesitis, dactilytis, uveitis), current age, age at psoriasis diagnosis, age at psoriatic arthritis diagnosis, PASI score and Schöber's test. These two tests were always applied by the same examiner. PASI score was applied with the aid of the pasimeter and data obtained were inserted and treated as a continuous variable $(0-72)$. Two patients had no-plaque type psoriasis and three had only nail psoriasis. PASI score was not evaluated in these patients but all the other variables were. The Schöber's test was applied with the patient standing. A little mark was made over the fifth lumbar vertebrae and another mark $10 \mathrm{~cm}$ above. The distance between these two marks was measured after the maximum frontal body bending. Normal result is $15 \mathrm{~cm}$.

The data generated were processed by SPSS statistical software version 15.0. Both HLA-B27 quantitative $(0-100 \%)$ and qualitative (positive or negative) were correlated with all variables mentioned above by Mann-Whitney's test, qui-square, two-tailed exact Fisher or Spearman's coefficient of correlation. Non parametric tests were used due to normality rejection by Kolmogorov-Smirnov's test. The statistical significance adopted was 5\%.

\section{RESULTS}

The average age of the patients was 52,9 yearsold $\pm 14,9$ (IC 48,4-57,4). Median age at psoriasis diagnosis was 36,2 years and at arthritis it was 43,4 . Most patients were male, (56,8\%), Caucasian (52,3\%), with high school degree $(40,9 \%)$, living in Rio de Janeiro (Table 1).

Plaque type psoriasis was the predominant finding (88,6\%) and PASI score was applied in all 39 patients with this phenotype. The average value was $4,71 \pm 4,6$ (IC 3,22-6,20) with a minimum of zero and maximum of 20,9. Lumbar spinal mobility was measured by the Schöber's test and it was $13,8 \mathrm{~cm} \pm$ 1,3 (IC 13,39 - 14,25) in average.

Among the 44 patients studied, thirty-two were negative for HLA-B27 (72.7\%). The antigen's value has varied from 0,1 to 99,1 with an average of 27,85 $\pm 29,3$. Positive HLA-B27 had significant correlation with male gender $(p=0,004)$. Negative HLA-B27 had a tendency to correlate with hands and wrists arthritis $(p=0,07)$ (Table 2). There was no significant association between HLA-B27 and race, psoriasis' physical symptoms, extra articular manifestations and none specific skin or joint involvement (except for hands and wrists).

Significant inverse correlation was found between HLA-B27 values and Schöber's test $(p=0,02)$. There was no significant correlation between HLAB27 and age at psoriasis diagnosis, arthritis diagnosis or PASI score.

\section{DISCUSSION}

The association of leukocyte antigen HLA-B27 with spondyloarthritis is well documented, although 
TABLE 1: Demographic and social characterization of a group of patients with psoriatic arthritis

\begin{tabular}{lcc}
\hline Demographic and social data & n & $\%$ \\
\hline Gender & 25 & 56,8 \\
Male & 19 & 43,2 \\
Female & & \\
Race & 23 & 52,3 \\
Caucasian & 12 & 27,3 \\
Brown race & 9 & 20,4 \\
African descent & & \\
& & \\
Educational level & 18 & 40,9 \\
High school & 17 & 38,6 \\
Basic education & 7 & 15,9 \\
University & & \\
Birthplace & & \\
Rio de Janeiro (city) & 16 & 36,4 \\
Other state & 15 & 34,1 \\
Rio de Janeiro (state) & 11 & 25 \\
Place of residence & & \\
Rio de Janeiro (city) & & \\
Rio de Janeiro (state) & 28 & 63,6 \\
\hline
\end{tabular}

Note: Some sums are not exact because less frequent results were suppressed the mechanisms leading to the development of immunepathological disease in this group are not fully elucidated. ${ }^{7}$ It is also known that the presence of this antigen is highly variable between different populations.

Data from the North-American literature presents HLA-B27 positivity from 10 to $25 \%$ in patients with psoriatic arthritis and 90\% in ankylosing spondylitis, but these findings are not specified by race or ethnic origin.

In Oviedo, northern Spain, HLA-B27 is found in $8.8 \%$ of the population. It is estimated that $17 \%$ of patients with psoriatic arthritis in this region are positive for this antigen. ${ }^{8}$ However, a study from 1990 has found positive HLA-B27 in 22\% of patients with psoriatic arthritis ${ }^{9}$ and in 2002 the observed frequency was $34 \% .{ }^{10}$ World wide the positivity of HLA-B27 may vary from $4 \%$, as confirmed by Israeli researchers to $36.4 \%$ as observed in the Brazilian state of Minas Gerais. ${ }^{11,12}$

In the state of São Paulo-Brazil, Bonfiglioli and colleagues investigated 102 patients with psoriatic arthritis and found positive HLA-B27 in $20.6 \%$ of the cases. The allele HLA-B*2705 was the most frequently observed. ${ }^{13}$

In our study, HLA-B27 was investigated in 44 patients and was mostly negative (72.7\%). Nevertheless, positive HLA-B27 was statistically asso-

TABLE 2: Association between HLA-B27 and race, gender, joint and extra articular manifestations

\begin{tabular}{|c|c|c|c|c|c|}
\hline \multirow[t]{2}{*}{ Clinical features } & \multicolumn{2}{|c|}{ HLA-B27 + } & \multicolumn{2}{|c|}{ HLA-B27 - } & \multirow[t]{2}{*}{$p$ value } \\
\hline & $\mathbf{n}$ & $\%$ & $\mathbf{n}$ & $\%$ & \\
\hline \multicolumn{6}{|l|}{ Gender } \\
\hline Male & 11 & 91,7 & 14 & 43,8 & 0,004 \\
\hline Female & 1 & 8,3 & 18 & 56,3 & \\
\hline \multicolumn{6}{|l|}{ Race } \\
\hline Caucasian & 7 & 58,3 & 16 & 50 & 0,87 \\
\hline Brown race & 3 & 25 & 9 & 28,1 & \\
\hline African descent & 2 & 16,7 & 7 & 21,5 & \\
\hline \multicolumn{6}{|l|}{ Joint manifestations } \\
\hline Hands / wrists arthritis & 8 & 66,7 & 29 & 90,6 & 0,07 \\
\hline Elbows & 6 & 50 & 12 & 37,5 & 0,45 \\
\hline Knees & 6 & 50 & 17 & 53,1 & 0,85 \\
\hline Feet / ankles arthritis & 8 & 66,7 & 19 & 59,4 & 0,73 \\
\hline Sacroiliacs & 2 & 16,7 & 4 & 12,9 & 1,00 \\
\hline \multicolumn{6}{|l|}{ Extra articular findings } \\
\hline Entesitis & 9 & 75 & 24 & 75 & 1,00 \\
\hline Dactylitis & 4 & 33,3 & 17 & 53,1 & 0,24 \\
\hline
\end{tabular}

Note: (1) The data presented were the ones related only to the presence of arthritis in the articulations mentioned. / (2) Some articulations and uveitis were omitted due to the low occurrence and impossibility of statistical interpretation. 
ciated with male gender, which agrees with other Brazilian studies. ${ }^{12,13}$ We observed a significant inverse correlation between HLA values and Schober's test, which assesses the lumbar spine flexibility.

If we consider that a normal test is $15 \mathrm{~cm}$, we can say that the patients used in this study had a good performance because the mean value found was 13.3 $\mathrm{cm}$. It is noteworthy that the evaluation measures of spinal mobility used in psoriatic arthritis are the same used in ankylosing spondylitis with similar performance. ${ }^{14}$ However, the axial involvement in psoriatic arthritis is usually milder than those seen in ankylosing spondylitis, as the prevalence of sacroiliitis is less severe and the mobility of the cervical and lumbar segments is more preserved. ${ }^{1}$

The inverse association between Schober's test measurement HLA-B27 values leads us to consider studies that correlate the presence of this antigen with axial disease. ${ }^{13,16}$ One manifestation of this pattern of involvement is a decreased test for lumbar flexibility.

At this study there was no significant association between HLA-B27 and race, physical symptoms of psoriasis, extra articular manifestations or any specific skin or joint involvement (except hands and wrists). There was also no correlation with PASI score, which leads us to believe that the severity of skin disease is independent of the presence or absence of the HLAB27 antigen.

\section{CONCLUSION}

In a group of 44 Brazilian patients with psoriatic arthritis HLA-B27 was mostly negative. Nevertheless, when this antigen was positive it was significantly correlated with male gender and inversely correlated with Schober's test.

\section{REFERENCES}

1. Moll JM, Wright V. Psoriatic arthritis. Semin Arthritis Rheum. 1973;3:55-78.

2. Gisondi P, Girolomoni G, Sampogna F, Tabolli S, Abeni D. Prevalence of psoriatic arthritis and joint complaints in a large population of Italian patients hospitalized for psoriasis. Eur J Dermatol. 2005;15:279-83.

3. Alves C, Vieira N, Meyer I, Alves C0, Toralles MBP, Oliveira, MFSP. Antígenos de histocompatibilidade humanos e dermatologia: da pesquisa para a prática clínica. An Bras Dermatol. 2006;81:65-73.

4. Antoni CE. Psoriatic arthritis: etiology and pathogenesis. In: Hochberg MC, Silman AJ, Smolen JS, Weinblatt ME, Weisman MH. Rheumatology. 4th ed. Philadelphia: Elsevier; 2008. p. 1129-77.

5. Maksymowych WP. Etiology, pathogenesis and pathology of ankylosing spondylitis In: Hochberg MC, Silman AJ, Smolen JS, Weinblatt ME, Weisman MH. Rheumatology. 4th ed. Philadelphia: Elsevier; 2008. p. 1115-81.

6. Eastmoond CJ, Woodrow JC. The HLA system and the arthropathies associated with psoriasis. Ann Rheum Dis. 1977;36:112-20.

7. Bruce IN. Psoriatic arthritis: clinical features. In: Hochberg MC, Silman AJ, Smolen JS, Weinblatt ME, Weisman MH. Rheumatology. 4th ed. Philadelphia: Elsevier; 2008 p. $1165-75$.

8. Gonzalez S, Garcia-Fernandez S, Martinez-Borra J, Blanco-Gelaz MA, Rodrigo L, Sanchez del Río J, et al. High variability of HLA-B27 alleles in ankylosing spondylitis and related spondyloarthropathies in the population of northern Spain. Hum Immunol. 2002:63:673-6.

9. López-Larrea C, Torre Alonso JC, Rodriguez Perez A, Coto E. HLA antigens in psoriatic arthritis subtypes of a Spanish population. Ann Rheum Dis. 1990;49:318-9.

10. Queiro R, Sarasqueta C, Belzunegui J, Gonzalez C, Figueroa M, Torre-Alonso JC. Psoriatic spondyloarthropathy: a comparative study between HLA-B27 positive and HLA-B27 negative disease. Semin Arthritis Rheum. 2002;31:413-8.

11. Elkayam 0 , Segal R, Caspi D. Human leukocyte antigen distribution in Israeli patients with psoriatic arthritis. Rheumatol Int. 2004:24:93-7.

12. Bomtempo CAS, Lage RC, Ferreira GA, Carvalho MAP. Avaliação clínica, laboratorial e radiográfica de brasileiros com espondiloartropatias. Rev Bras Reumatol. 2006;46:238-45

13. Bonfiglioli R, Conde RA, Sampaio-Barros PD, Louzada-Junior P, Donadi EA, Bertolo MB. Frequency of HLA-B27 alleles in Brazilian patients with psoriatic arthritis. Clin Rheumatol. 2008;27:709-12.

14. Fernández-Sueiro JL, Willisch A, Pértega-Díaz S, Tasende JAP, Fernández-Lopez C, Galdo $\mathrm{F}$, et al. Evaluation of ankylosing spondylitis spinal mobility measurements in the assessment of spinal involvement in psoriatic arthritis. Arthritis Rheum. 2009;61:386-92

15. Gladman DD, Brubacher B, Busckila D, Langevitz P, Farewell VT. Differences in the expression of spondyloarthropathy: a comparison between ankylosing spondylitis and psoriatic arthritis. Clin Invest Med. 1993;16:1-7.

16. Gladman DD, Farewell VT, Kopciuk KA, Cook RJ. HLA markers and progression in psoriatic arthritis. J Rheumatol. 1998;24:730-3.

How to cite this article: Ruiz DG, Azevedo MNL, Lupi O. HLA-B27 frequency in a group of patients with psoriatic arthritis. An Bras Dermatol. 2012;87(6):847-850. 